\title{
Analysis of the Influence of the Emotional, Intellectual and Spiritual Intelligence on Employee Performance with Work Motivation as a Moderating Variable
}

\author{
Cheng-Wen LEE ${ }^{1}$ \\ Alum KUSUMAH²
}

\begin{abstract}
The importance of this study is to identify the influence of emotional, intellectual and spiritual intelligence factors on employee performance, through work motivation as a moderating variable in the PIKP Company, bridging the gap between existing research literature and offering an empirical reference to the industry's experience. This study demonstrates an empirical analysis by taking a quantitative approach to identifying and explaining the degree of the variables' influence on the hypotheses proposed. The emotional intelligence and intellectual variable demonstrated a positive and significant influence on the performance of the employee while the variable of spiritual intelligence had a positive but not significant influence. As for the moderating variable, the test results obtained on the performance of the employee reveal the results of the test hypotheses which vary. The empirical findings in this study were obtained through t-test and Moderated Regression Analysis (MRA).
\end{abstract}

KEYWORDS: Emotional intelligence, Employee performance, Intellectual intelligence, Spiritual intelligence, Work motivation.

JEL CLASSIFICATION: $M 12, M 54$

\section{INTRODUCTION}

Confronted with globalization and industrial revolution 4.0, businesses can no longer escape intense business rivalry. In the face of fierce business competition, decision-making and determination of effective and efficient strategies are required, in order to survive and expand their company in an increasingly competitive environment. One of the things businesses need to concern about is how to manage all of their resources, especially human resources. Almasri (2016) notes that the effective management of human resources can improve employee performance and productivity to achieve organizational goals. Therefore, to improve company performance, companies are required to be able to encourage their employees to provide optimal performance so as it can influence overall company performance (Igwe, 2014).

Employee performance is a form of problem that every company will always encounter. The company's policies should be able to positively affect and promote employee expectations to enhance employee productivity in line with the company's desired expectations (Vosloban, 2012). However, the abilities and other intelligence that workers possess, including the ability to manage their self, and the ability to build relationships with others, which is called emotional intelligence, also influence the ability to improve employee performance. (Mudayat, 2017). There is another intelligence called intellectual intelligence, following

\footnotetext{
${ }^{1}$ Chung Yuan Christian University, Taiwan, chengwen@cycu.edu.tw

${ }^{2}$ Chung Yuan Christian University, Taiwan, alumkusumah@gmail.com (The corresponding author)
} 
emotional intelligence. Intellectual intelligence is an ability to analyze and take constructive and efficient action to solve a problem (Widyawati \& Karwini, 2019).

Furthermore, another intelligence that is also called spiritual intelligence, where this competence helps one to think creatively, to have a long vision, to make or to alter a rule so that the individual can work a lot better. Spiritual intelligence can be used to combine the previous two other intelligence: emotional intelligence and intellectual intelligence (Kulshrestha \& Singhal, 2017). Whether the knowledge and expertise can be adequately utilized and used, job motivation can be affected to mutually boost the efficiency of the employees (Alkahtani, 2015). Job motivation is a force for directing the behaviors of a person towards the completion of a job based on defined objectives; therefore, motivation becomes an important issue and a determining factor in enhancing employee performance, although each approach taken by each company appears to be different in motivating its employees. Motivation is vital to employee success and plays a significant role in the efficiency and other behaviors (Ghaffari et al., 2017).

\subsection{Problem statement}

Before this study conducted, pre-study activities were performed at PIKP Company. Based on the phenomenon observed, where an employee retention program has been undertaken at PIKP Company since 2018 to reduce the number of employees with a significant number and gradually until 2020 to automate and optimize the company-owned production lines. Employees not impacted by the retention program are deemed by the employer to have the requisite ability and competence to continue to work and to manage their respective work areas. The workload kept by workers who are still employed would increase with the decreasing number of employees compared to before, but the wages and income tend to remain constant. The authors are therefore interested in examining the influences of emotional, intellectual and spiritual intelligence for employees on the performance of the employee with job motivation as a moderating variable.

\subsection{Background of the case company}

PIKP Company is a paper manufacturing company that operates in Riau Province, Indonesia. PKIP Company manufactures a range of paper products, including photocopy paper and large size paper. This company's paper commodities are marketed domestically and imported into different countries around the globe. The manufacturing strategy prioritizes labor-intensive and semi-automatic production line approaches from the start of the business (the 70s) to 2016 where a production flow approach to a complete production line is designed to modernize by modernizing production equipment and reducing human intervention in the production process.

\subsection{Research gap}

There is not much study on emotional, intellectual and spiritual intelligence relevant to the paper-manufacturing sector, which at the same time runs an employee retention system aimed at improving the production line and shifting the paradigm into automation and production line modernization. The essential importance of this study is to bridge and enrich the disparity between current research literatures by providing a scientific resource for use by related industries. Moreover, it can be used as a reference for further studies on emotional intelligence, intellectual, spiritual, work motivation and employee performance and other relevant studies. 


\subsection{The objective of the study}

The main objective of this study is to analyze and identify the influence of emotional, intellectual and spiritual intelligence factors on employee performance, through work motivation as a moderating variable in the PIKP Company.

\section{LITERATURE REVIEW}

\subsection{Employee performance}

The definition of employee performance is the results that employees obtain in doing their jobs and also the outcome of an interaction between ability and motivation (Robbins et al., 2012). Motivating workers is one of the tasks that the organization should carry out through its leadership elements to encourage the employee to carry out the job with full responsibility (Siagian, 2014). Furthermore, Simamora (2015) noted that the aim and objective of the working performance are to set useful targets and not only to assess at the end of a certain period but also to evaluate the results of the work process during that time.

Chishti et al., (2010) identified three work performance indicators such as:

a. Punctuality, ensuring workers to complete their work within a predetermined period.

b. Job description, employee achievement in performing tasks according to the defined job description.

c. Work quality, workers can recognize and address relevant results, and also have a good working attitude.

Further, Sedarmayanti (2017) notes that the organization will benefit from the positive performance of the employees: a) improved abilities and skills of employees; b) improve working conditions and the quality of job outcomes; c) the optimal development and utilization of workers; d) encourage the establishment of healthy relationships between superiors and subordinates; e) employees are aware of the organization's condition; f) employees are aware of their strengths and weaknesses so that their growth can be encouraged.

\subsection{Emotional intelligence (emotional quotient / EQ)}

Mayer and Salovey (in Fiori and Vesely-Maillefer, 2019) define emotional intelligence as social intelligence related to individuals' ability to control their emotions and the emotions of others, as well as their ability to differentiate their emotions from other people's emotions, where this ability is used to direct patterns of thought and behavior. This interpretation is also in line with the definition of emotional intelligence by Shapiro (2009), that mentioned as a series of mental functions involving the ability to monitor the intensity of feelings or emotions, on oneself as well as on others. Individuals with high emotional intelligence have self-belief, are full of enthusiasm, and are good at figuring things out and using the information to direct their thoughts and behavior.

Goleman (2002) further addresses the fundamental factors of emotional intelligence:

a. Self-awareness is a person's ability to know the emotions inside himself, to use it to make choices about himself, to have practical goals, to have a deep faith in connecting with the root of the problem.

b. Self-management, including the capacity to regulate their feelings, the emotions expressed and controlled, the sensitivity to the conscience used in everyday life.

c. Empathy is the capacity to feel what others feel, to understand others' perspectives and to be able to contribute to a mutual trust relationship.

Boyatzis (2008) discovered that those who can control their emotions well would be able to produce good performance; emotional intelligence is a factor equally critical as a combination 
of technical and analytical skills to produce optimal performance. Besides, Hess and Bacigalupo (2013) also revealed that employees with high scores of emotional intelligence would deliver good output, where it can be seen how the quality and quantity these employees deliver to the company.

H1: Emotional intelligence influences positively and significantly the employee's performance

\subsection{Intellectual intelligence (intellectual quotient / IQ)}

Intellectual intelligence is an intellectual, analytical, logical, and ratio ability. A person with good intellectual intelligence does not need to collect difficult information; it can store and process anything. The intellectual intelligence method can be described as the process of obtaining, storing and reprocessing information or commonly referred to as thought (Nuraini, 2017). Sunar (2010) mentioned that the ability to function abstractly using ideas, symbols, logical relationships, and theoretical concepts can be described as intellectual intelligence (IQ). The ability to recognize, learn, and use these abstractions, and to overcome occurring problems. Intellectual Intelligence works to measure speed, measure new things, store and remember detailed information and play an active role in numbers counting, respectively. Intellectual intelligence emphasizes the ability of logical thinking to effectively discover objective facts, to anticipate risks and to see the implications of any current decision (Putri, 2016).

Hariwijaya describes (in Sa'diyah, 2011), intellectual intelligence has several indicators, such as:

a. Verbal intelligence is intelligence belonging to someone who can communicate in order, organized, systematic, precise diction and the positioning of self. This intelligence relates to the ability of clearly organizing thoughts and being able to use them competently through words to convey thoughts in speaking, reading, and writing.

b. Rationale intelligence, that is, intelligence possessed by someone that combines reasoning ability and knowledge. Logic is very important for decision making in daily life.

c. Numerical Intelligence, an intelligence a person possesses that includes numbers-related abilities.

d. Spatial intelligence is a person's intelligence, which includes the ability to capture "space" with all its consequences. Artists, photographers, architects, carver, and designers usually own this skill.

Wiramiharja (2003) discovered that there is a positive and significant correlation between intellectual intelligence and work performance. Wiramiharja further explained that success in carrying out a job would be better for someone who has good intellectual intelligence, though specific skills do play an important role in predicting how to generate an individual's performance.

$\mathrm{H} 2$ : Intellectual intelligence influences positively and significantly the employee's performance

\subsection{Spiritual intelligence (spiritual quotient / SQ)}

Zohar and Marshall (2001) describe spiritual intelligence as the intelligence to address and solve problems of meaning and value, notably intelligence to position human behavior and existence within the sense of a larger and richer meaning, intelligence to determine whether individual acts or way of life are more important than another. Like the other two types of intelligence (IQ and EQ), spiritual intelligence may be increased and decreased to limitlessly expand its capacity to be. Spiritual intelligence works effectively to function intellectual intelligence and emotional intelligence to enable someone with high spiritual intelligence to be an individual with strong principles and vision to understand every aspect of life and to manage and survive in adversity (Agustian 2007). 
The elements in the business world required in spiritual intelligence are as follows (Sukidi, 2002):
a. Consistency of honesty: in parallel to saying the truth, and behaving consistently.
b. Openness: accountability and transparency.
c. Self-knowledge: being able to measure yourself and understand yourself.
d. Focus on contribution: emphasize giving rather than receiving.
e. Spiritual non-dogmatic: the ability to be flexible, and the ability to confront and exploit obstacles.

Spiritual intelligence arises because of the intellectual intelligent and emotional intelligence debate and considered as a part of the contribution and as a determinant of success in life. As other factors play a role, notably spiritual intelligence, where this knowledge focuses more on the meaning of life and not just the emphasis on spirituality alone (Hoffman in Hasanuddin \& Sjahruddin, 2017).

H3: Spiritual intelligence influences positively and significantly the employee's performance

\subsection{Work motivation}

Robbins (in Velnampy, 2014) mentioned that motivation reflects the willingness to make the greatest effort to achieve organizational goals through the effort made to satisfy individual needs. This is also in line with the definition of motivation by Luthans (2009), which states that motivation is a drive that is shown to achieve certain goals. Also, Manullang (2015) further explained that a person needs the accomplishment to achieve success or satisfaction and it takes motivation from outside (extrinsic factors) and the inside (intrinsic factors). Sutrisno (2016) specifically cites these factors, such as:

a. Extrinsic factors consisting of an enjoyable working environment, adequate compensation, effective management, job security, status and responsibilities, and flexible regulations.

b. Intrinsic factors consisting of the desire to live, the desire to have, the desire to obtain appreciation, the desire to obtain recognition and the desire to rule.

The objective of providing employee motivation, as Hasibuan (2014) mentioned that motivation aims to: a) encourage enthusiasm and passion for the work; b) increase morale and work satisfaction; c) increase productivity at work; d) maintaining stability and loyalty; e) raising discipline; f) rationalizing the hiring of workers; g) creating good working relationships and the environment; $h$ ) boost creativeness and commitment; i) improve welfare level; j) improve the sense of responsibility for assigned tasks; $k$ ) increase the use of the equipment and raw materials efficiently.

An employee is driven by the strong motivations that drive the employee to perform duties. However, based on more dominant motivations at the moment, the employee will behave or comply according to certain ways that contribute to satisfying their needs (Manullang, 2015).

\subsection{Moderating variable}

According to Ghozali (2016), moderating variable is one type of variable that can strengthen or even weaken a direct relationship that exists between the independent variable and the dependent variable, because apart from the influence between the independent variable and the dependent variable in a study, there is also the possibility of influence from other variables. Because of the relation between the independent variable and the dependent variable, the moderating variable is created. Work motivation is utilized as a moderating variable in this study.

$\mathrm{H} 4 \mathrm{a}$ : Work motivation moderates the influence of emotional intelligence on the performance of employees.

$\mathrm{H} 4 \mathrm{~b}$ : Work motivation moderates the influence of intellectual intelligence on the performance of employees. 
$\mathrm{H} 4 \mathrm{c}$ : Work motivation moderates the influence of spiritual intelligence on the performance of employees.

\subsection{Previous study}

There are several previous studies about emotional, intellectual and spiritual intelligence on employee performance, such as a study performed by Widyawati \& Karwini (2019), which conducted intelligence and emotional intelligence analysis on employee performance on the employee of PT Karna Titian Denpasar Sejahtera, Bali, with a total amount of 174 respondents. It was found in the study that both intellectual and emotional intelligence had a positive and significant influence on the performance of the employees. This supports the prior study performed by Priyono (2015), who researched civil servants with 112 respondent employed in the language center of East Java province, Indonesia, discovered that variables measured such as emotional, intellectual, and spiritual intelligence have had a positive and significant influence on employee performance in these government agencies. Both of these studies, therefore, employed an empirical and quantitative approach to the analysis.

Another research conducted by Siswanti et al., (2018) explores the influence of spiritual intelligence, emotional intelligence, and social competence on leadership qualities on aviation authorities in Makassar, Indonesia. This study employs an explanatory approach with a survey involving 900 respondents. The methodology of data processing uses the form of the Structural Equation (SEM). The study findings obtained are spiritual intelligence, and emotional competence has a direct influence on leadership qualities but no direct influence on social skills towards leadership qualities.

\subsection{Research framework}

The proposed research framework and hypotheses to be discussed as follows:

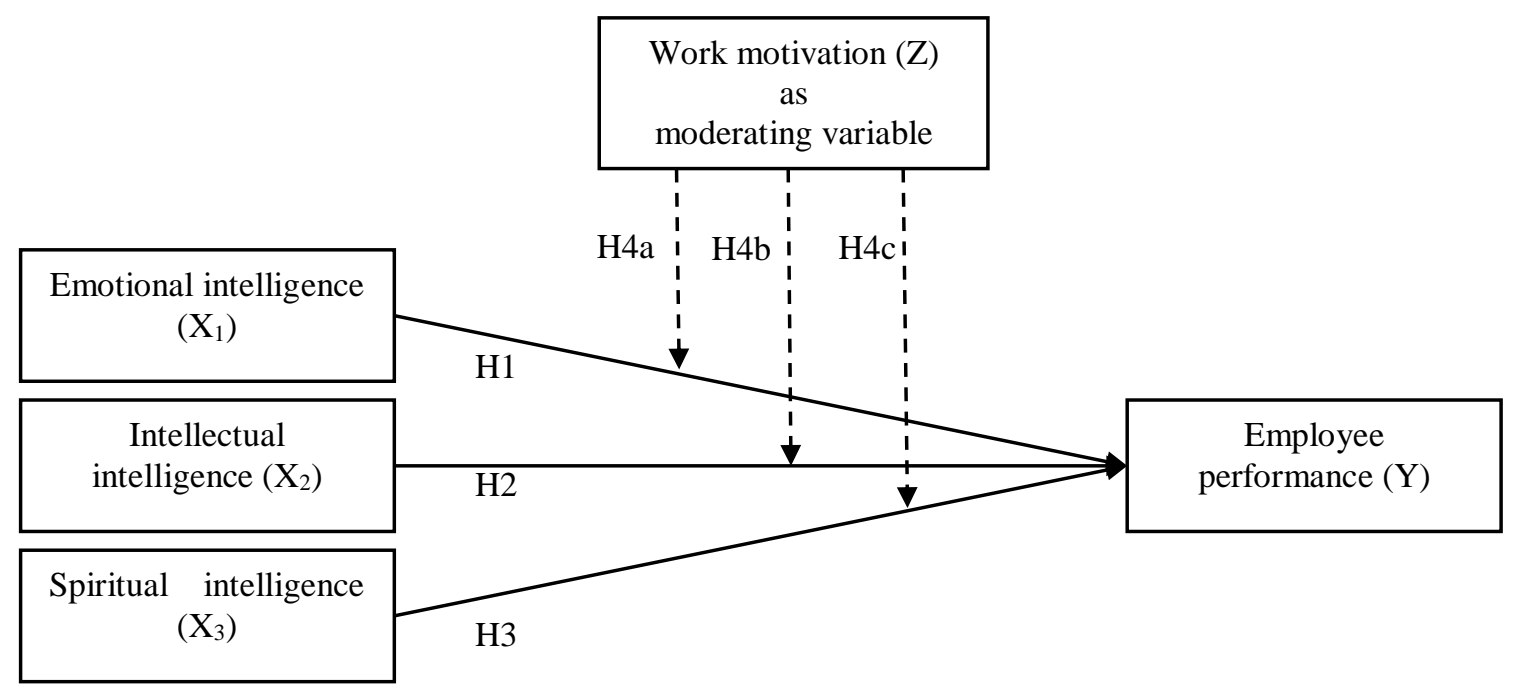

Figure 1. Research framework

Source: own elaboration

\section{RESEARCH METHODOLOGY}

This work is an empirical and quantitative study using primary and secondary data. The primary data were collected using data collection techniques through questionnaires to PIKP Company employees who were identified as respondents using accidental sampling methods 
to as many as 107 individuals. The accidental sampling method is a technique used to collect data from samples that unintentionally interact with the author and are considered as a data source. Secondary data generated from the literature and other related information from different sources relevant to the data required.

The unit of measurement used for independent and dependent variables utilizes a Likert scale, with the questionnaire answers weighing as follows: 1 (strongly disagree); 2 (disagree); 3 (neutral); 4 (agree) and 5 (strongly agree). The quantitative analysis includes the validity test, the reliability test and the classical assumption test (normality test, multicollinearity test and heteroscedasticity test). Subsequently, the next step is to analyze and evaluate the hypothesis through the t-test, as well as to evaluate the moderating variables using MRA (Moderated Regression Analysis). The analysis is performed using SPSS (Statistical Package for the Social Sciences) ver. 22.0.

\subsection{Research sampling}

The number of respondents obtained and determined based on the opinion of Hair et al., (2017) which states that at least 5-10 times the number of indicator variables used is the number of samples used. The number of questionnaires given to sampled employees was 115 questionnaires, but 107 questionnaires were considered worthy of testing because they were completely and correctly filled in. The respondents involved in the study were identified by age, gender, educational level and work experience (Table 1). Within the age, classification divided into four age categories, with 21 respondents for ages 20 - 30 years (19.63\%). The age of the majority of respondents is then $>30-40$ years, with 50 participants and a percentage of $46.73 \%$. About the age group from $>40$ - 50 years as many as 21 respondents $(19.63 \%)$ while the rest are older than 50 years (15 or $14.02 \%)$. The next description of the respondent is about gender, where the highest number of respondents comprises 90 males with a presentation of $84.11 \%$ and the remaining are female.

Table 1. Respondent demographics

\begin{tabular}{|c|c|c|c|}
\hline \multicolumn{2}{|c|}{$\begin{array}{c}\text { Description of respondents } \\
(\mathbf{N}=\mathbf{1 0 7})\end{array}$} & Frequency & $\%$ \\
\hline \multirow{4}{*}{ Age } & $20-30$ years & 21 & 19.63 \\
\cline { 2 - 4 } & $>30-40$ years & 50 & 46.73 \\
\cline { 2 - 4 } & $>40-50$ years & 21 & 19.63 \\
\cline { 2 - 4 } & $>50$ years & 15 & 14.02 \\
\hline \multirow{4}{*}{ Gender } & Male & 90 & 84.11 \\
\hline \multirow{4}{*}{ Educational level } & Female & 17 & 15.89 \\
\cline { 2 - 4 } & High School & 58 & 54.21 \\
\cline { 2 - 4 } & Undergraduate & 37 & 34.58 \\
\cline { 2 - 4 } & Graduate & 12 & 11.21 \\
\hline \multirow{4}{*}{ Duration of tenure } & $0-5$ years & 9 & 8.93 \\
\cline { 2 - 4 } & $>5-10$ years & 20 & 24.11 \\
\cline { 2 - 4 } & $>10-15$ years & 47 & 37.50 \\
\cline { 2 - 4 } & $>15-20$ years & 16 & 17.86 \\
\cline { 2 - 4 } & $>20$ years & 15 & 11.61 \\
\hline
\end{tabular}


The respondents' level of education was divided into high school, undergraduate, and graduate. For the high school level as the most respondents with 58 respondents (54.20 percent) followed by the undergraduate level with 37 students. The others are 12 participants with graduate degree (11.21 percent). For tenure duration divided into 5 categories. Most respondents with tenure $>10-15$ years are $47(37.50 \%)$ then followed by respondents with tenure $>5-10$ years with a total of 20 participants or $24.11 \% .15$ respondents $(11.61 \%)$ with a working period of $>20$ years and the rest are respondents with tenure between $0-5$ years.

\section{FINDING AND DISCUSSION}

\subsection{Validity and reliability test}

\subsubsection{Validity test}

A validity test is a measurement to assess an instrument's accuracy in carrying out its measuring function. A measuring instrument is said to have high validity if it provides measuring results according to measuring purpose (Ghozali, 2016). Ghozali also stated that if an r-count > r-table value is obtained the minimum requirement for an element to be considered valid. The validity test was performed on each variable's instruments with the following details: 9 indicators of emotional intelligence; 12 indicators of intellectual intelligence; 15 indicators of moral intelligence, 15 indicators of work motivation and 9 indicators of employee performance. It would then examine a total of 60 indicators.

Table. 2 Validity test result

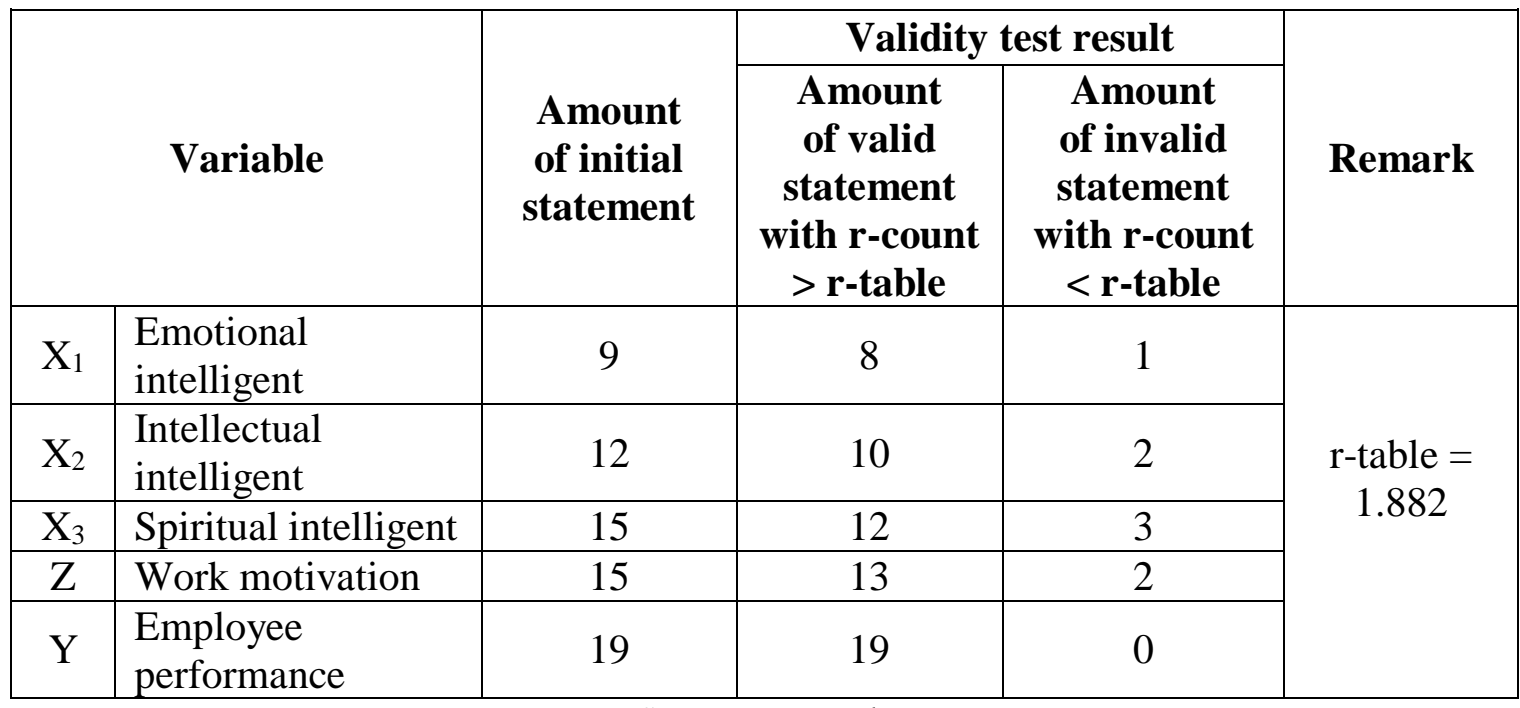

Source: own study

According to Table 2, there are invalid statements (r-count $<$ r-table) based on the validity check which is subsequently not used for further testing with invalid statements. The value of the r-table is 1.882. The invalid statements of each indicator tested for validity are: the emotional intelligence variable $\left(\mathrm{X}_{1}\right)$ indicator decreased by 1 statement, the total statement used is reduced from the initial 9 statements to 8 statements. Furthermore, the intellectual intelligence variable $\left(\mathrm{X}_{2}\right)$ decreased by 2 statements, from 12 statements to 10 ; the spiritual intelligence variable $\left(\mathrm{X}_{3}\right)$ is reduced from 15 statements to 12 statements; work motivation is reduced from 15 statements to 13 . The valid statements will be used for the next analysis. 


\subsubsection{Reliability test}

Table 3. Reliability test result

\begin{tabular}{|c|r|r|l|}
\hline Variables & $\begin{array}{c}\text { Cronbach's } \\
\text { alpha }\end{array}$ & $\begin{array}{c}\text { Number } \\
\text { of items }\end{array}$ & Remark \\
\hline $\begin{array}{c}\text { Emotional intelligent } \\
\left(\mathrm{X}_{1}\right)\end{array}$ & 0.825 & 8 & Reliable \\
\hline $\begin{array}{c}\text { Intellectual intelligent } \\
\left(\mathrm{X}_{2}\right)\end{array}$ & 0.881 & 10 & Reliable \\
\hline $\begin{array}{c}\text { Spiritual intelligent } \\
\left(\mathrm{X}_{3}\right)\end{array}$ & 0.858 & 12 & Reliable \\
\hline Work motivation & 0.871 & 13 & Reliable \\
\hline $\begin{array}{c}\text { Employee performance } \\
(\mathrm{Y})\end{array}$ & 0.830 & 9 & Reliable \\
\hline \multicolumn{2}{|c|}{ Source: own study } &
\end{tabular}

Reliability test is a test performed to evaluate the questionnaire which is an indicator of a variable that can be said to be reliable if the answers of the respondent are consistent from time to time, where a variable is considered reliable if the Cronbach alpha value $>0.60$ (Ghozali, 2016). The reliability test results (Table 3) for the variables used demonstrated that the Cronbach alpha value obtained was $>0$. It can be stated that the entire variables tested for reliability are considered acceptable for the next analysis.

\subsection{Classic assumption test}

\subsubsection{Multicollinearity test}

The next analysis is testing on multicollinearity. The multicollinearity test was performed to evaluate whether the regression model found a correlation between independent variables. Ghozali (2016) stated the consequence of a high correlation between independent variables is that the variable's regression coefficient is sensitive to data changes, and the influence of individual independent variables on the dependent variable cannot be excluded. Multicollinearity testing is done by measuring tolerance value and Variance Inflation Factor (VIF). To imply that there are no signs of multicollinearity in the regression model, the tolerance value must be $>0.10$ and the VIF value for each independent variable and the moderating variable $<10$.

The results obtained (table 4) after assessing the multicollinearity of the independent and moderating variables are emotional intelligence (X1) has a tolerance value of 0.287 and a VIF value of 3.484. Moreover, for the Intellectual Intelligence (X2) variable the tolerance and VIF value has a value of 0.303 and 3.297. According to the test results, the tolerance value in the spiritual intelligence variable is 0.888 , and the VIF value is 1.127 . For work motivation as a moderation variable a tolerance value of 0.887 and a VIF value of 1.126 were obtained. The values of the independent and moderating variables have a tolerance value $>0.10$ and a VIF value $<10$ from the values of the multicollinearity test results, and it can be inferred that there are no symptoms of multicollinearity within the regression model. 
Table 4. Multicollinearity test result

\begin{tabular}{l|c|c|c|c}
\hline $\begin{array}{c}\text { Collinearity } \\
\text { Statistic }\end{array}$ & $\begin{array}{c}\text { Emotional } \\
\text { intelligent } \\
\left(\mathbf{X}_{\mathbf{1}}\right)\end{array}$ & $\begin{array}{c}\text { Intellectual } \\
\text { intelligent } \\
\left(\mathbf{X}_{\mathbf{2}}\right)\end{array}$ & $\begin{array}{c}\text { Spiritual } \\
\text { intelligent } \\
\left(\mathbf{X}_{\mathbf{3}}\right)\end{array}$ & $\begin{array}{c}\text { Work } \\
\text { motivation } \\
\mathbf{( Z )}\end{array}$ \\
\hline Tolerance & 0.287 & 0.303 & 0.888 & 0.887 \\
VIF & 3.484 & 3.297 & 1.127 & 1.126 \\
\hline \multicolumn{4}{|c}{ Source: own study }
\end{tabular}

\subsubsection{Heteroskedasticity test}

The purpose of the heteroscedasticity test is to examine if there is an unequal variance between the residuals of one observation and another in the regression model. A good model of regression is the model of homoscedasticity, that is, the variance between the residuals of one observation and another is fixed and, if it is different, is called heteroscedasticity (Ghozali, 2016). Ghozali also mentioned that it is possible to use scatterplot diagrams to detect heteroscedasticity, by adding the predicted variable values to the residuals. Once the distribution of data forms a certain pattern (spread pattern then narrows or vice versa) along the diagonal line (the Y-axis at the top and bottom of the number of 0 ) then there has been heteroscedasticity.

The conclusions drawn for heteroscedasticity analysis (figure 2) reveal that the data scatter randomly between the Y-axis and zero and do not form a specific pattern so that the regression model has no symptoms of heteroscedasticity. The regression model stated to be ideal and feasible to use.

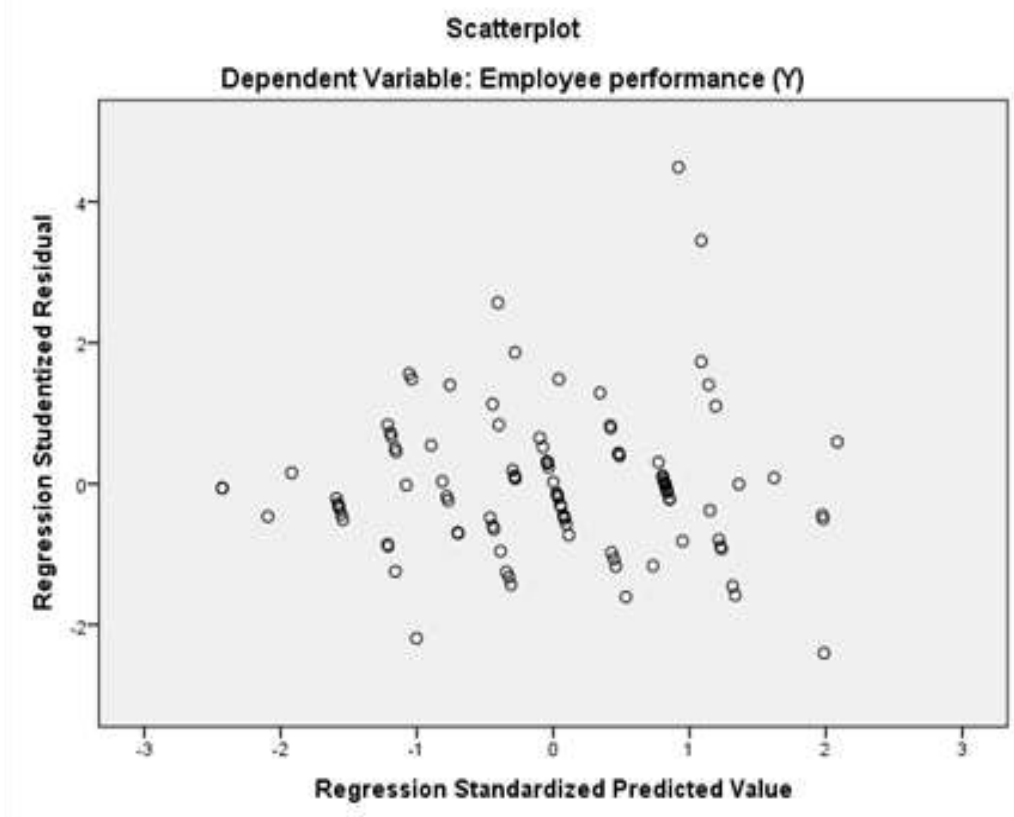

Figure 2. Scatterplot diagram Source: own study 


\subsubsection{Normality test}

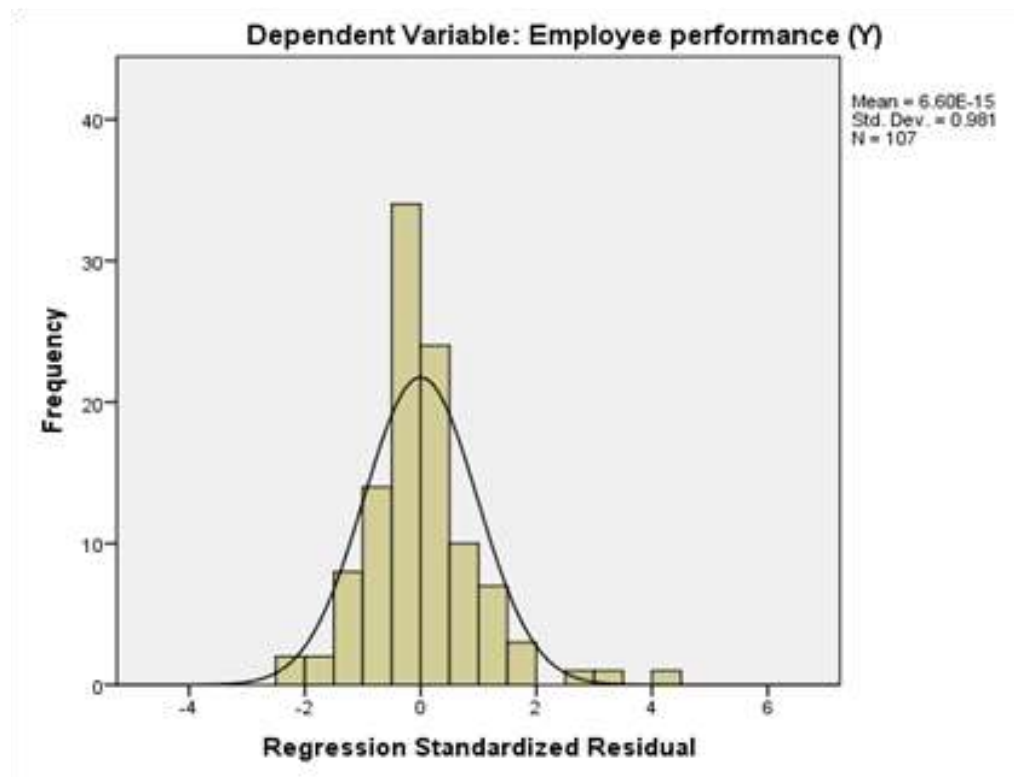

Figure 3. Histogram

Source: own study

The normality test is used to determine if the residuals have a normal distribution in the regression model. As it violates this assumption then the statistical test is invalid or biased. A good model of data is normally distributed, or near normal. It is done by paying attention to the bell-shaped histogram chart and the normal probability plot that is normally distributed forming a diagonal line to display normally distributed data (Ghozali, 2016).

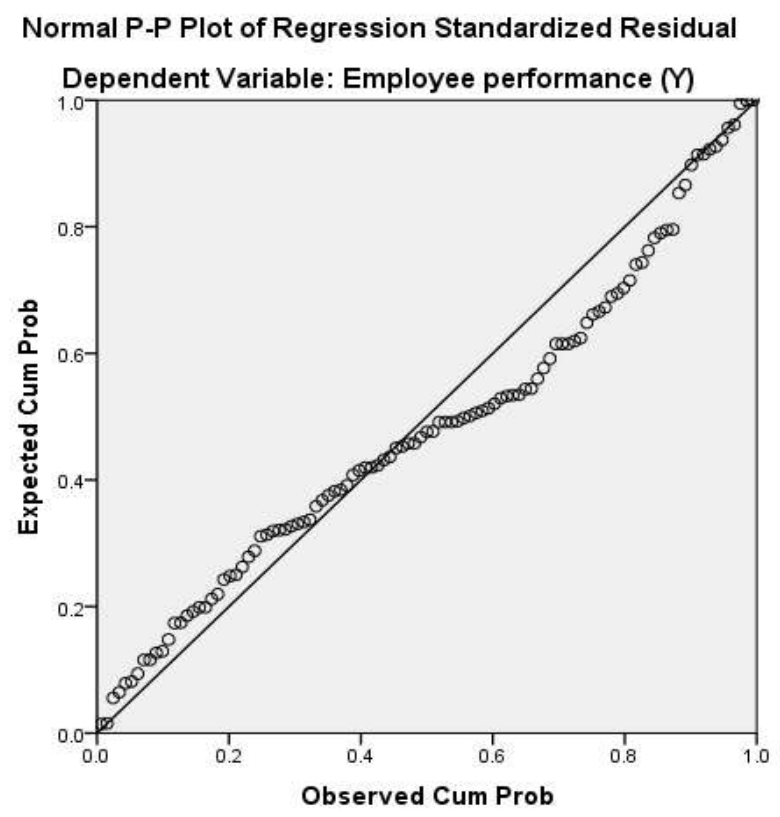

Figure 4. P-P Plot graph

Source: own study

The results of the normality test using a histogram (figure 3) show that the data from each variable patterns like a symmetrical bell shape on the right and left sides, this indicates the tendency of the data to be distributed normally. Also supporting this conclusion is the 
distribution of residual points on the P-P plot graph (fig. 4), shown to follow and approach the diagonal line so that it is assumed that the regression model meets the assumption of normality.

\subsubsection{Hypothesis test}

To confirm the proposed hypotheses, the study uses the approach of t-test and Moderated Regression Analysis (MRA), with an explanation as follows:

\subsubsection{1 t-test}

The t-test is a regression coefficient test of each independent variable to determine the influence value of the independent variables on the dependent variable (Sugiyono, 2016). In determining the influence of the examined variables, the following conditions are used: a) the hypothesis is accepted, if the value of $t$-count $>t$-table, then the independent variable (X) influences the dependent variable $(\mathrm{Y})$; b) the hypothesis is rejected, if the value of $\mathrm{t}$-count $<\mathrm{t}$-table then the independent variable does not influence the dependent variable. The obtained t-test results are as follows:

The results of the t-test revealed the values of $t$ and Sig. as shown in table 5. The defined $\mathrm{t}$-table value is 1.983. Emotional intelligence $\left(\mathrm{X}_{1}\right)$ obtained t-count 29,777 > t-table 1.983 and Sig. $0.000<0.05$. The variable of intellectual intelligence $\left(\mathrm{X}_{2}\right)$, with a value of $\mathrm{t}$-count $5,876>$ t-table 1.983 and Sig. $0.000<0.05$, while spiritual intelligence (X3) obtained t-count $1.129<$ t-table 1.983 with Sig. 0.261 (Sig. $0.261>0.05$ ).

Table 5. t-test result

\begin{tabular}{c|r|r|r}
\hline & $\begin{array}{c}\text { Emotional } \\
\text { intelligent } \\
\left(\mathbf{X}_{1}\right)\end{array}$ & $\begin{array}{c}\text { Intellectual } \\
\text { intelligent } \\
\left(\mathbf{X}_{2}\right)\end{array}$ & $\begin{array}{c}\text { Spiritual } \\
\text { intelligent } \\
\left(\mathbf{X}_{3}\right)\end{array}$ \\
\hline $\mathrm{t}$ & 29.777 & 5.876 & 1.129 \\
$\mathrm{Sig}$ & .000 & .000 & 0.261 \\
\hline \multicolumn{3}{|c}{ Dependent Variable: Employee performance (Y) } \\
\multicolumn{3}{c}{ Source: own study }
\end{tabular}

\subsubsection{Moderated regression analysis (MRA)}

The moderating variable used in this analysis is work motivation $(\mathrm{Z})$ which is a variable capable of strengthening or weakening the relationship or influence between the independent variable and the dependent (Helm \& Mark, 2012). This study uses Moderate Regression Analysis (MRA) to test the interaction significance associated with a combination of independent variables and moderating variables on the dependent variable. Decision making procedure used if the outcome of the significance probability is Sig. $\leq 0.05$, then the hypothesis is accepted, and the hypothesis is rejected if Sig. $>0.05$. 
Table 6. MRA test result

\begin{tabular}{|c|c|c|c|c|c|c|c|c|c|}
\hline Model & & $\mathbf{t}$ & Sig. & & $\mathbf{t}$ & Sig. & & $\mathbf{t}$ & Sig. \\
\hline \multirow{4}{*}{1} & (Constant) & -2.107 & .038 & (Constant) & 1.695 & .093 & (Constant) & $\begin{array}{r}1.11 \\
3\end{array}$ & .268 \\
\hline & $\begin{array}{l}\text { Emotional } \\
\text { intelligent } \\
\qquad\left(\mathrm{X}_{1}\right)\end{array}$ & $\begin{array}{r}10.58 \\
9\end{array}$ & .000 & $\begin{array}{l}\text { Intellectual } \\
\text { intelligent } \\
\left(\mathrm{X}_{2}\right)\end{array}$ & 1.513 & .133 & $\begin{array}{l}\text { Spiritual } \\
\text { intelligent } \\
\left(\mathrm{X}_{3}\right)\end{array}$ & .101 & .920 \\
\hline & $\begin{array}{c}\text { Work } \\
\text { motivation } \\
(Z)\end{array}$ & 2.479 & .015 & $\begin{array}{c}\text { Work } \\
\text { motivation } \\
(\mathrm{Z})\end{array}$ & 1.042 & .300 & $\begin{array}{c}\text { Work } \\
\text { motivation } \\
(\mathrm{Z})\end{array}$ & .973 & .333 \\
\hline & $\mathrm{ZX}_{1}$ & -2.507 & .014 & $\mathrm{ZX}_{2}$ & 1.147 & .254 & $\mathrm{ZX}_{3}$ & .561 & .576 \\
\hline
\end{tabular}

Dependent Variable: Employee performance (Y)

Source: Own study

Based on the results of the Moderated Regression Analysis (MRA), the following test results (Table 6) were obtained for the significance of each independent variable moderated by job motivation $(\mathrm{Z})$ on employee performance $(\mathrm{Y})$. Emotional intelligence $\left(\mathrm{X}_{1}\right)$ with a value of 0.14 (Sig. $\leq 0.05$ ); intellectual intelligence $\left(\mathrm{X}_{2}\right)$ with a value of 0.254 (Sig. $>0.05$ ); and intellectual intelligence $\left(\mathrm{X}_{3}\right)$ of 0.576 (Sig. > 0.05).

\subsubsection{Hypothesis test results}

After completion of the hypothesis test, the outcome is summarized conceptually (Table 7), with the following explanation:

Table 7. Hypotheses test result

\begin{tabular}{c|l|c}
\hline \multicolumn{1}{|c|}{ Hypothesis } & Conclusion \\
\hline $\mathrm{H} 1$ & $\begin{array}{l}\text { Emotional intelligence influences positively and } \\
\text { significantly the employee's performance. }\end{array}$ & Accepted \\
\hline $\mathrm{H} 2$ & $\begin{array}{l}\text { Intellectual intelligence influences positively and } \\
\text { significantly the employee's performance. }\end{array}$ & Accepted \\
\hline $\mathrm{H} 3$ & $\begin{array}{l}\text { Spiritual intelligence influences positively and } \\
\text { significantly the employee's performance. }\end{array}$ & Rejected \\
\hline $\mathrm{H} 4 \mathrm{a}$ & $\begin{array}{l}\text { Work motivation moderates the influence of } \\
\text { emotional intelligence on the performance of } \\
\text { employees. }\end{array}$ & Accepted \\
\hline $\mathrm{H} 4 \mathrm{~b}$ & $\begin{array}{l}\text { Work motivation moderates the influence of } \\
\text { intellectual intelligence on the performance of } \\
\text { employees. }\end{array}$ & Rejected \\
\hline $\mathrm{H} 4 \mathrm{c}$ & $\begin{array}{l}\text { Work motivation moderates the influence of } \\
\text { spiritual intelligence on the performance of } \\
\text { employees. }\end{array}$ & Rejected \\
\hline
\end{tabular}

Source: own study 
Hypothesis 1 (H1): Emotional intelligence influences positively and significantly the employee's performance - accepted. This is shown by the positive value found in the $\mathrm{t}$-count $=29.777$ and $\mathrm{t}$-count $29.777>\mathrm{t}$-table 1.983 also with Sig. $0.014<0.05$ (significant).

Hypothesis 2 (H2): Intellectual intelligence influences positively and significantly the employee's performance - accepted. Hypothesis 2 with positive value of $t$-count $=5.876$ and t-count $5.876>$ t-table 1.983, with Sig. value obtained Sig. $0.000<0.05$ (significant).

Hypothesis 3 (H3): Spiritual intelligence influences positively and significantly the employee's performance - rejected. Hypothesis 3 has a positive t-count value of 1.129 hence it is below the t-table value (t-count $1.129<\mathrm{t}$-table 1.983). The Sig. value worth of $0.261>0.05$ (not significant).

Hypothesis 4a (H4a): Work motivation moderates the influence of emotional intelligence on the performance of employees - accepted. Sig. value obtained based on the MRA test output $=0.014$, in Sig. $0.014<0.05$ (significant).

Hypothesis 4b (H4b): Work motivation moderates the influence of intellectual intelligence on the performance of employees - rejected. Hypothesis $4 \mathrm{~b}$ is rejected because of the Sig. value is obtained based on the results of the MRA test $=0.254$ (Sig. $0.254>0.05$ $=$ not significant).

Hypothesis 4c (4c): Work motivation moderates the influence of spiritual intelligence on the performance of employees - rejected. The results MRA test obtained by Sig. 0.576, where the value of Sig. $0.576>0.05$ (not significant).

\section{CONCLUSION, IMPLICATION \& LIMITATION}

\subsection{Conclusion}

Based on the test results of the six hypotheses proposed, the following conclusions are drawn: First, the results of the t-tests, and Sig. values implied that the independent variables evaluated on the dependent variable revealed that: H1 was accepted. It is indicated by the results of the t-test, where the t-count value exceeds the t-table and the Sig. value less than the probability value. It also applies to the $\mathrm{H} 2$. The $\mathrm{H} 3$ was rejected on the contrary, although the outcome of the t-test had a positive (+) value but had no significant influence because it had a Sig. value less than the predetermined probability value.

Second, moderation variable testing using MRA provides the following description with varied test results: Hypothesis 4a (H4a) with the output of MRA test showing the Sig. less than the designated probability value. $\mathrm{H} 4 \mathrm{a}$ is then declared acceptable. Although for hypothesis $4 \mathrm{~b}(\mathrm{H} 4 \mathrm{~b})$ and Hypothesis $4 \mathrm{c}(\mathrm{H} 4 \mathrm{c})$ are rejected. The outcomes of MRA tests $(\mathrm{H} 4 \mathrm{~b}$ and $\mathrm{H} 4 \mathrm{c}$ ) produce similar results that are contrary to $\mathrm{H} 4 \mathrm{a}$, where both results of MRA tests on $\mathrm{H} 4 \mathrm{~b}$ and $\mathrm{H} 4 \mathrm{c}$ indicate Sig. exceeds the defined probability.

\subsection{Theoretical implication}

The results obtained in this study contribute to scientific references and understanding of the influence of emotional, intellectual and spiritual intelligence, moderated by work motivation on the performance of employees in one of the companies in the paper industry. The study also encourages the improvement of organizational behavior by explaining the positive influence of emotional, intellectual and spiritual intelligence on the performance of the employees.

\subsection{Managerial implication}

The outcomes of this study can be used as input for the elements of management to consider developing their employees' level of intelligence with purpose is to boost organizational 
performance by improving the performance of the employees. Among the essential efforts that must be developed is to tailor the training programs according to the organizational goals and the needs of the employees.

\subsection{Limitation}

The limitation experienced in this study is that the analysis performed only on one manufacturing company engaged in paper production. Therefore, it can explain only the conditions that exist in a particular company. Furthermore, this study also relied solely on the respondents 'perceptions as outlined in the questionnaire, and was considered very subjective. Limitations are also seen in the variables used are limited to four variables, such as emotional intelligence, intellectual, spiritual and work motivation, since there are still other variables that influence employee performance that need to be further explained. For further studies, exploring employee performance with the different study populations, different variables and different research approaches is recommended, to expand the literature on employee performance, notably in the framework of interacting with the challenge of Industry 4.0.

\section{REFERENCES}

Agustian, A. G. (2007). Emotional Spiritual Quotient, The ESQ Way 165. Jakarta: Arga Publishing.

Alkahtani, A. H. (2015). The Influence of Leadership Styles on Organizational Commitment: The Moderating Effect of Emotional Intelligence. Business and Management Studies, 2(1), 23-34. https://doi.org/10.11114/bms.v2i1.1091.

Almasri, M. N. (2016). Manajemen Sumber Daya Manusia: Implementasi Dalam Pendidikan Islam. Jurnal Penelitian Sosial Keagamaan, 19, 133-151. https://doi.org/ 10.1002/eji.201370106.

Boyatzis, R. (2008). Competencies in the 21st century. Journal of Management Development, 27(1), 5-12. https://doi.org/10.1108/02621710810840730.

Chishti, S. H., Rafiq, M., Rahman, F., Jumani, N. B. \& Ajmal, M. (2010). Impact of Participative Management on Employee Job Satisfaction and Performance in Pakistan. Journal Academic, 10, 12-23.

Dessler, G. (2017). Human Resources Management (15th ed.). New Jersey: Pearson Higher Education.

Fiori, M. \& Vesely-Maillefer, A. K. (2019). Correction to: Emotional Intelligence as an Ability: Theory, Challenges, and New Directions. In Emotional Intelligence as an Ability: Theory, Challenges, and New Directions (pp. 23-42). https://doi.org/10.1007/978-3-319-90633-1_17.

Ghaffari, S., Burgoyne, J. \& Nazri, M. (2017). The Influence of Motivation on Job Performance: A Case Study at Universiti Teknologi Malaysia. Australian Journal of Basic and Applied Sciences, (March), 92-99.

Ghozali, I. (2016). Aplikasi Analisis Multivariate Dengan Program IBM SPSS 23 (8th ed.). Semarang: Badan Penerbit Universitas Diponegoro.

Goleman, D. (2002). Emotional Intelligence. Jakarta: PT. Gramedia Pustaka Utama. 
Hair, J. F., Black, W. C., Babin, B. J. \& Anderson, R. E. (2017). Multivariate Data Analysis (MVDA). In Pharmaceutical Quality by Design: A Practical Approach (7th ed.). https://doi.org/10.1002/9781118895238.ch8.

Hasanuddin, R. \& Sjahruddin, H. (2017). The Structure of Emotional Intelligence, Spiritual Intelligence and Its Relationship with Work Enthusiasm and Auditor Performance. World Journal of Business and Management, 3(1), 67. https://doi.org/ 10.5296/wjbm.v3i1.11321.

Hasibuan, M. S. P. (2014). Organization \& Motivation: Rising Productivity. Jakarta: Bumi Aksara.

Helm, R. \& Mark, A. (2012). Analysis and evaluation of moderator effects in regression models: State of art, alternatives and empirical example. Review of Managerial Science, 6(4), 307-332. https://doi.org/10.1007/s11846-010-0057-y.

Hess, J. \& Bacigalupo, A. (2013). Applying Emotional Intelligence Skills to Leadership and Decision Making in Non-Profit Organizations. Administrative Sciences, 3(4), 202-220. https://doi.org/10.3390/admsci3040202.

Igwe, A. (2014). Effective Human Resource Management As a Tool For Organizational Success. European Journal of Business and Management, 6(39), 210-219.

Kulshrestha, S. \& Singhal, T. K. (2017). Impact of Spiritual Intelligence on Performance and Job Satisfaction: A Study on School Teachers. International Journal of Human Resource \& Industrial Research, 4(2), 1-6. https://doi.org/10.5281/zenodo.343742.

Luthans, F. (2009). Organizational Behavior. The McGraw-Hill/Irwin (12th ed.). https://doi.org/10.5005/jp/books/10358_23.

Manullang, M. (2015). Fundamentals of Management (23rd ed.). Yogyakarta: Gadjah Mada University Press.

Mudayat (2017). Connecting Emotional Spiritual Quotient and Employment Status with Performance. International Journal of Managerial Studies and Research, 5(1), 19-23. https://doi.org/10.20431/2349-0349.0501005.

Nuraini, F. (2017). Kecerdasan Emosional, Kecerdasan Intelektual dan Kecerdasan Spiritual Terhadap Pemahaman Akuntansi Dasar Dengan Motivasi Sebagai Variabel Moderating. Journal of Accounting Science, 1(2), 93. https://doi.org/10.21070/jas.v1i2.892.

Priyono (2015). Effect of intellectual intelligence, emotional intelligence, and spiritual intelligence to performance civil servants Language Center East Java. International Journal of Applied Business and Economic Research, 13(9), 7067-7079.

Putri, Y. S. (2016). Pengaruh Kecerdasan Intelektual, Kecerdasan Emosional, Dan Lingkungan Kerja Terhadap Kinerja Karyawan Pt. Pln Persero Area Klaten. Jurnal Studi Manajemen Organisasi, 13(1), 88-97. https://doi.org/10.14710/jsmo.v13i1.13416.

Robbins, S. T., Judge, T. A. \& Hasham, E. S. (2012). Organizational Behavior (13th ed.; F. Gibbons, ed.). Retrieved from http://www.pearsonmiddleeastawe.com/pdfs/OBSAMPLE.pdf.

Sedarmayanti (2017). Manajemen Sumber Daya Manusia. Bandung: Refika Aditama.

Shapiro, D. (2009). Untapped power: emotions in negotiation. In Negotiation: readings, exercises and cases (pp. 139-146). New York: Mcgraw-Hill.

Siagian, S. P. (2014). Human Resources Management. Jakarta: Bumi Aksara. 
Simamora, H. (2015). Human Resources Management. Yogyakarta: STIEY.

Siswanti, D. N., Khairuddin, R. \& Halim, F. (2018). The Effect of Spiritual Intelligence, Emotion and Social Competence on Leadership Competence. Journal of Physics: Conference Series, 1028(1). https://doi.org/10.1088/1742-6596/1028/1/012193.

Sugiyono (2016). Metode Penelitian Kuantitatif, Kualitatif dan R\&D. Bandung: PT. alfabeta.

Sukidi (2002). Kecerdasan Spiritual. Mengapa SQ Lebih Penting daripada IQ \& EQ. Jakarta: Gramedia Pustaka Utama.

Sunar, P. (2010). Edisi lengkap tes $I Q, S Q \& S Q$. Yogyakarta: Best Publisher.

Sutrisno, E. (2016). Human Resources Management (8th ed.). Jakarta: Kencana.

Velnampy, T. (2014). Factors influencing motivation: An Empirical study of few selected Sri Lanka Organisations. (1964), 1-12.

Vosloban, R. I. (2012). The Influence of the Employee's Performance on the Company's Growth - A Managerial Perspective. Procedia Economics and Finance, 3(12), 660-665. https://doi.org/10.1016/s2212-5671(12)00211-0.

Widyawati, S. R. \& Karwini, N. K. (2019). The Effect of Intelligence Quotient and Emotional Quotient on Employee Performance at Pt. Karna Titian Sejahtera Denpasar. International Journal of Contemporary Research and Review, 10, 21401-21407. https://doi.org/https://doi.org/10.15520/ijcrr.v10i01.669.

Zohar, D. \& Marshall, I. (2001). SQ: Spiritual Intelligence - The Ultimate Intelligence (Hebrew). Jerusalem. 